\title{
Detection of selected bacterial species in intraoral sites of patients with chronic periodontitis using multiplex polymerase chain reaction
}

\author{
Cyntia Rodrigues de Araújo ESTRELA ${ }^{1}$, Fabiana Cristina PIMENTA², Ana Helena Gonçalves de ALENCAR $^{3}$, \\ Luis Fernando Naldi RUIZ ${ }^{4}$, Carlos ESTRELA ${ }^{5}$ \\ 1- DDS, MSc, PhD, Institute of Biological Sciences, Federal University of Goiás, Goiânia, GO, Brazil. \\ 2- MSc, PhD, Professor of Microbiology, Institute of Tropical Pathology and Public Health, Federal University of Goiás, Goiânia, GO, Brazil. \\ 3- DDS, MSc, PhD, Professor of Endodontics, Department of Oral Science, Federal University of Goiás, Goiânia, GO, Brazil. \\ 4- DDS, MSc, PhD, Professor of Periodontics, Department of Oral Science, Federal University of Goiás, Goiânia, GO, Brazil. \\ 5- DDS, MSc, PhD, Chairman and Professor of Endodontics, Department of Oral Science, Federal University of Goiás, Goiânia, GO, Brazil.
}

Corresponding address: Prof. Dr. Carlos Estrela - Centro de Ensino e Pesquisa Odontológica do Brasil - (CEPOBRAS) - Avenida C-198, Quadra 487, Lote 9, Jardim América - 74.270-040 - Goiânia, GO - Brazil - e-mail: estrela3@terra.com.br

Received: February 7, 2009 - Modification: September 2, 2009 - Accepted: February 16, 2010

\section{ABSTRACT}

\begin{abstract}
O bjective: The aim of this study was to detect the prevalence of selected bacterial species in intraoral sites of patients with chronic periodontitis (CP) using multiplex polymerase chain reaction (PCR). Methodology: Samples were collected from the tongue dorsum, buccal mucosa, supragingival and subgingival plaque and saliva of 30 patients with untreated CP. Multiplex PCR was used to determine prevalence rates, which were then compared using a chi-square test. Significance level was set at $p<0.05$. Mean and standard deviation values were used to evaluate variations in prevalence according to site. Results: The prevalence of S. mutans was $70 \%$ in saliva; $60 \%$ in samples collected from the tongue dorsum; $50 \%$ in samples collected from the buccal mucosa; $56.5 \%$ in the supragingival plaque; and $53.5 \%$ in the subgingival plaque. The prevalence of $E$. faecalis ranged from $3.5 \%$ to $13.5 \%$ in all intraoral microenvironment. The highest prevalence of $P$. gingivalis was found in subgingival plaque $(53.5 \%)$, and of $P$. intermedia in supragingival plaque $(33.5 \%)$, subgingival plaque $(30 \%)$ and tongue dorsum $(33.5 \%)$. The prevalence of bacteria did not vary significantly among the intraoral sites. Conclusions: All studied bacteria were identified in intraoral sites. S. mutans, $P$. gingivalis and $P$. intermedia had high prevalence rates, but the prevalence of $E$. faecalis was low. Multiplex PCR proved to be an adequate method for epidemiological studies.
\end{abstract}

Key words: Chronic periodontitis. Bacteria. DNA probes. PCR. Epidemiological studies.

\section{INTRODUCTION}

More than 700 species of microorganisms, such as Gram-positive and Gram-negative bacteria, yeast, protozoa and viruses, are found in the oral cavity ${ }^{21}$. Microorganisms are distributed in four oral ecosystems - tongue dorsum, buccal mucosa, supragingival and subgingival plaques. Saliva keeps direct contact with oral tissues; it contains cells from different sites of the mouth that may spread as plaque or planktonic suspension?.

Streptococcus mutans, Enterococcus faecalis, Porphyromonas gingivalis, Prevotella intermedia are bacterial species that knowingly cause several oral diseases, such as dental caries, endodontic infections and periodontal diseases ${ }^{7,14,19,27}$.

S. mutans are Gram-positive facultative bacteria that have been implicated as a primary cause of dental caries in humans. One of the important virulence properties of these microorganisms is the ability to form a biofilm, known as dental plaque, on tooth surfaces ${ }^{13,14}$. Some of the bacterial components associated with the adhesion phase of S. mutans are glucosyltransferases, protein antigen $\mathrm{C}$ and glucan-binding proteins. The number and distribution of genotypes of $S$. mutans isolated from caries-active and caries-free children were used to evaluate some of their phenotypic traits. There were differences in the distribution of genotypes of S. mutans according to the oral site, and S. mutans 
populations differ in their susceptibility to acid and ability to form plaque, factors that lead to their colonization of sucrose-rich environments ${ }^{13}$.

$E$. faecalis has an important role in endodontic infections because of particular strategies to form plaque, substantial virulence factors, adherence to dentin collagen, survival in critical environments, and resistance to endodontic therapy. E. faecalis is a Gram-positive coccus, a facultative anaerobe, found in normal human gastrointestinal infections and common in secondary apical periodontitis. Enterococci are classified as the second to third most common organisms found in hospital-acquired infections, and $85-95 \%$ of these isolates are $E$. faecalis ${ }^{19}$.

$P$. gingivalis is a Gram-negative anaerobe that resides in subgingival plaque and is associated with severe and chronic cases of periodontal disease, a condition characterized by destruction of the tissue supporting the teeth ${ }^{4}$. A number of factors are associated with the virulence of this oral anaerobe, including a variety of proteases, endotoxins, and collagenase, as well as the production of surface structures such as fimbriae and capsular polysaccharides ${ }^{10}$.

$P$. intermedia are also Gram-negative anaerobes found in the orange complex ${ }^{25}$; they are blackpigmented Bacteroides prevalent in acute necrotizing ulcerative gingivitis ${ }^{15}$ due to CP progression ${ }^{7}$. This species has several of the virulent properties of $P$. gingivalis and induces mixed infections when inoculated in laboratory animals ${ }^{9}$. Its virulence factor is determined by its capability of adhesion to hard surfaces and soft tissues of the oral cavity ${ }^{6}$.

Several studies used polymerase chain reaction (PCR) to detect selected bacterial species in the oral cavity $7,12,20,22$. The multiplex variant of PCR can be used for the simultaneous amplification of two or more loci in the same reaction ${ }^{23}$.

Success in the treatment of intraoral infectious diseases depends on the knowledge of the prevalence of the bacterial species associated with etiological factors. Therefore, this study detected $S$. mutans, E. faecalis, $P$. gingivalis and $P$. intermedia in several intraoral sites of patients with chronic periodontitis using multiplex PCR technique.

\section{MATERIALS AND METHODS}

\section{Subjects}

Thirty adults with chronic periodontitis (22 women; mean age: $37 \pm 5$ years) and teeth with vital pulps were selected from a group of patients seeking treatment at the Brazilian Dental Association in Goiânia, GO, Brazil. All participants were in good general health.

Patients were included in the study if they had a clinical diagnosis of chronic periodontitis and no history of odontogenic pain. Exclusion criteria were: pregnancy, systemic problems that might affect periodontal disease activity; or use of antimicrobial medication or antimicrobial treatment in the 3 months before inclusion in the study. None of the patients included in the study had previously received any type of periodontal treatment. All patients signed an informed consent form before inclusion, and the study protocol was approved by the Research Ethics Committee of the Institute of Biological Sciences of Goiás Federal University, Goiânia, GO, Brazil (protocol \# 65/2006, ICB, UFG).

\section{Clinical examination}

Clinical measurements were performed at six intraoral sites (mesiobuccal, buccal, distobuccal, distolingual, lingual and mesiolingual positions) on each tooth except the third molar at a baseline visit. Clinical parameters measured were: pocket depth $(\mathrm{mm})$; bleeding on probing (0 or 1$)$; suppuration ( 0 or 1 ); and plaque accumulation ( 0 or 1 ). Saliva, oral mucosa and supra- and subgingival plaque samples for microbiological assessment were collected before clinical measurements. All patients provided samples of soft tissue and supra- and subgingival plaque. This model of clinical examination was described in previous studies ${ }^{17,26}$.

\section{Sampling procedures}

Samples were collected from saliva, buccal mucosa, tongue dorsum and supra- and subgingival plaques, in this sequence. Aseptic techniques were used during all the study.

Saliva samples were collected by immersing two sterilized \#50 absorbent paper points (Tanari, Tanariman Indústria, Ltda., Manacaru, AM, Brazil) in non-stimulated saliva for 1 minute; the paper points were then placed in Eppendorf-like tubes containing $500 \mu \mathrm{L}$ of sterile PBS buffer. For the other intraoral sites, samples were collected by gently rubbing epithelial and dental surfaces for 1 minute with two \#50 sterile absorbent paper points. Supraand subgingival plaque samples were collected from 2 different sites. Samples from supragingival plaque were collected with gently rubbing dental surfaces with two paper points and samples from subgingival plaque were collected with a two sterile \#50 absorbent paper points introduced into the periodontal pocket maintained for $1 \mathrm{~min}$. The absorbent paper points were placed in Eppendorflike tubes containing $500 \mu \mathrm{L}$ of sterilized PBS buffer. All the samples were immediately frozen at $-20^{\circ} \mathrm{C}$ for posterior analysis.

The teeth selected for the collection of supraand subgingival plaque samples had no caries and were vital; pulp vitality was tested with dichlorodifluoromethane spray (cold test, $-20^{\circ} \mathrm{C}$, Aeroget, Ind. Bras., São Paulo, SP, Brazil). 


\section{Bacterial strains and DNA isolation}

Samples were evaluated using multiplex PCR. For DNA extraction, the samples were thawed under refrigeration, vortex-mixed for $1 \mathrm{~min}$, and then centrifuged at $5000 \mathrm{rpm}$ for $5 \mathrm{~min}$. The initial volume of $500 \mu \mathrm{L}$ was reduced to $300 \mu \mathrm{L}$ to increase the concentration of microbial cells. Samples were boiled in water bath for $10 \mathrm{~min}$, and then frozen at $-20^{\circ} \mathrm{C}$. Reference DNA for the microorganisms under analysis (S. mutans - ATCC 25175, E. faecalis - ATCC 29212, P. gingivalis - ATCC 33277 and P. intermedia - ATCC 25611) were also extracted to serve as positive controls.

\section{PCR assay}

The PCR reaction to determine the presence of all microorganisms was performed in $25 \mu$ of reaction mixture containing $13.05 \mu \mathrm{L}$ of ultrapure water, $2.5 \mu \mathrm{L}$ of $10 X$ PCR Buffer (Invitrogen, Carlsbad, CA, USA), $1.75 \mu \mathrm{L}$ of $50 \mathrm{mM} \mathrm{MgCl} 2$ (Invitrogen, Carlsbad, CA, USA), $1.0 \mu \mathrm{L}$ of each primer ( $50 \mathrm{mM} /$ $\mu \mathrm{L}$ ) (E. faecalis $\mathrm{F}$ - GTT TAT GCC GCA TGG CAT AAG AG, E. faecalis R - CCG TCA GGG GAC GTT CAG, S. mutans F - ACT ACA CTT TCG GGT GGC TTG G, S. mutans R - CAG TAT AAG CGC CAG TTT CAT C) (Invitrogen, Carlsbad, CA, USA), $0.5 \mu \mathrm{L}$ of 10 mM dNTP Mix (ie, deoxyadenosine triphosphate, deoxycytidine triphosphate, deoxyguanosine triphosphate, and deoxythymidine triphosphate; Invitrogen, Carlsbad, CA, USA) and $0.2 \mu \mathrm{L}$ of Taq DNA Polymerase (Invitrogen, Carlsbad, CA, USA). Ultrapure water was used in the place of bacterial
DNA template in each PCR reaction as a negative control, and extracted DNA from the reference microorganisms (ATCC) was used as a positive control.

PCR amplification was performed in a DNA thermocycler (Mastercycler Gradient, Eppendorf, Hamburg, Germany). Thermal cycling parameters for E. faecalis and $S$. mutans were: initial denaturation at $95^{\circ} \mathrm{C}$ for $5 \mathrm{~min}$, followed by 36 cycles of denaturation at $95^{\circ} \mathrm{C}$ for $30 \mathrm{~s}$, primer-annealing at $60^{\circ} \mathrm{C}$ for $1 \mathrm{~min}$, extension at $72^{\circ} \mathrm{C}$ for $1 \mathrm{~min}$, and a final step at $72^{\circ} \mathrm{C}$ for $10 \mathrm{~min}$; for $P$. gingivalis and $P$. intermedia, initial denaturation at $94^{\circ} \mathrm{C}$ for $5 \mathrm{~min}$, followed by 36 cycles of denaturation at $94^{\circ} \mathrm{C}$ for 1 min, primer-annealing at $56^{\circ} \mathrm{C}$ for $1 \mathrm{~min}$, extension at $72^{\circ} \mathrm{C}$ for $2 \mathrm{~min}$, and a final step at $72^{\circ} \mathrm{C}$ for 10 min. ( $P$. gingivalis $F$ - AGG CAG CTT GCC ATA CTG CG, $P$. gingivalis R - ACT GTT AGC AAC TAC CGA TGT, $P$. intermedia F - CGT GGA CCA AAG ATT CAT CGG TGG A, P. intermedia R - CCG CTT TAC TCC CCA ACA AA).

The PCR amplicons were analyzed using electrophoresis in $1 \%$ agarose gel (Invitrogen, Carlsbad, CA, USA) in Tris-borate-EDTA buffer. The gel was stained for $30 \mathrm{~min}$ with $1 \mathrm{mg} / \mathrm{ml}$ ethidium bromide and visualized under ultraviolet light. Reactions were classified as positive when bands of expected sizes were detected. A Lambda Hind (Invitrogen, Carlsbad, CA, USA) 100 bp ladder was used as a size marker.

The prevalence of bacteria in intraoral sites was analyzed with a chi-square test, and the level

Table 1- Prevalence of bacterial species in samples from different intraoral sites

\begin{tabular}{|c|c|c|c|c|c|}
\hline Bacteria & Intraoral sites & $\mathbf{n}$ & Presence & $x^{2}$ & $p$ \\
\hline \multirow[t]{5}{*}{ S. mutans } & Saliva & 30 & $21(70 \%)$ & 2.901 & 0.575 \\
\hline & Tongue dorsum & 30 & $18(60 \%)$ & & \\
\hline & Buccal mucosa & 30 & $15(50 \%)$ & & \\
\hline & Supragingival plaque & 30 & $17(56.5 \%)$ & & \\
\hline & Subgingival plaque & 30 & $16(53.5 \%)$ & & \\
\hline \multirow[t]{5}{*}{ E. faecalis } & Saliva & 30 & $1(3.5 \%)$ & 3.214 & 0.523 \\
\hline & Tongue dorsum & 30 & $4(13.5 \%)$ & & \\
\hline & Buccal mucosa & 30 & $1(3.5 \%)$ & & \\
\hline & Supragingival plaque & 30 & $2(6.5 \%)$ & & \\
\hline & Subgingival plaque & 30 & $2(6.5 \%)$ & & \\
\hline \multirow[t]{5}{*}{$P$. gingivalis } & Saliva & 30 & $7(23.5 \%)$ & 8.734 & 0.068 \\
\hline & Tongue dorsum & 30 & $7(23.5 \%)$ & & \\
\hline & Buccal mucosa & 30 & $9(30 \%)$ & & \\
\hline & Supragingival plaque & 30 & $12(40 \%)$ & & \\
\hline & Subgingival plaque & 30 & $16(53.5 \%)$ & & \\
\hline \multirow[t]{5}{*}{ P. intermedia } & Saliva & 30 & $7(23.5 \%)$ & 1.093 & 0.895 \\
\hline & Tongue dorsum & 30 & $10(33.5 \%)$ & & \\
\hline & Buccal mucosa & 30 & $8(26.5 \%)$ & & \\
\hline & Supragingival plaque & 30 & $10(33.5 \%)$ & & \\
\hline & Subgingival plaque & 30 & $9(30 \%)$ & & \\
\hline
\end{tabular}

(chi-square test) (SPSS Inc., v.15 for Windows, Chicago, IL, EUA) 


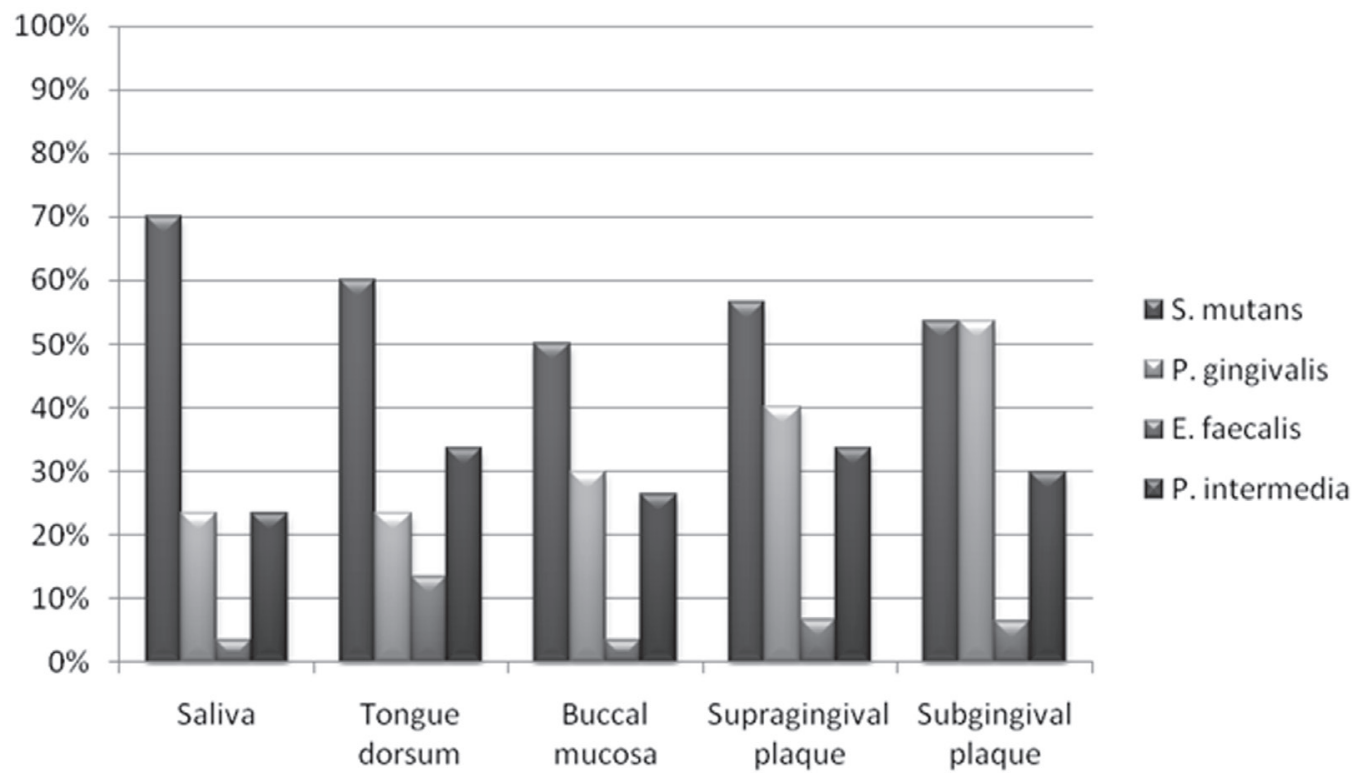

Figure 1- Frequency of selected bacterial species in different intraoral sites

of significance was set at $p<00.5$ (SPSS; Inc., v.15 for Windows, Chicago, IL, USA). Mean and standard deviation values were used to evaluate the variations of bacterial prevalence rates according to intraoral sites.

\section{RESULTS}

The bacteria selected and their prevalence in intraoral sites are shown in Table 1 . The depth of periodontal pockets in $55 \%$ of the cases was $\geq$ $4 \mathrm{~mm}$, and in $45 \%, \geq 6 \mathrm{~mm}$. S. mutans was detected in $70 \%$ of saliva samples; $60 \%$ of tongue dorsum samples; $50 \%$ of buccal mucosa samples; $56.5 \%$ of supragingival plaque samples; and $53.5 \%$ of subgingival plaque samples.

The prevalence of $E$. faecalis was $3.5 \%$ in saliva; $13.5 \%$ in the tongue dorsum; $3.5 \%$ in the buccal mucosa; $6.66 \%$ in supragingival plaque; and $6.5 \%$ in subgingival plaque. The prevalence of $P$. gingivalis was $23.5 \%$ in both saliva and the tongue dorsum; $30 \%$ in the buccal mucosa; $40 \%$ in supragingival plaque; and $53.5 \%$ in subgingival plaque. For $P$. intermedia, prevalence rates were $23.5 \%$ in saliva samples; $33.5 \%$ in the tongue dorsum; $26.5 \%$ in the buccal mucosa; $33.5 \%$ in supragingival plaque; and $30 \%$ in subgingival plaque (Figure 1 ). There were no statistically significant differences $(p>0.05)$ between saliva and samples collected from the other intraoral sites for the bacteria studied. Bacterial prevalence remained independent from site analyzed, which was demonstrated by the relatively constant value of standard deviations for the studied sites (according to type of bacteria). Mean prevalence values for $P$. intermedia were the closest to the general mean prevalence rates according to sites investigated.

\section{DISCUSSION}

Oral diseases, such as dental caries and endodontic and periodontal infections, are often associated with important etiological agents, such as S. mutans, E. faecalis, $P$. gingivalis and $P$. intermedia.

The determination of bacterial prevalence rates in all sites under study at the same time and in association with $\mathrm{CP}$ was an important characteristic of this study because saliva establishes direct contact between four oral ecosystems, which are important reservoirs for infection.

The bacteria selected for this study play an important role in oral microbial ecology. The microorganisms that colonize the oral environment produce plaques of different complexities depending on intraoral site, genetic background and individual environmental factors ${ }^{7}$. Socransky and Haffajee ${ }^{25}$ (1991) reported that once periodontal tissues are colonized, evidence suggests that only a subsequent species causes destructive periodontal disease. To colonize subgingival sites, bacteria must attach to one or more of the available surfaces, multiply, compete successfully against other species for that habitat, and defend itself from host defense mechanisms.

The prevalence of $S$. mutans in the studied microenvironments was elevated (greater than $50 \%$ ). This bacterial species is the one most often studied in the human mounth ${ }^{14,20}$. Wu, et al. ${ }^{29}$ (2003) found that the prevalence of S. mutans in supragingival plaques in individuals with dental caries was $75.4 \%$. The prevalence rate in our study was lower $(56.5 \%)$, but participants' teeth were 
free of caries.

The prevalence of $E$. faecalis was lower in all intraoral sites $(3.5 \%$ to $13.5 \%)$. This type of bacteria is common in gastrointestinal infections and secondary endodontic infections. Colombo, et al. ${ }^{2}$ (2002) determined the subgingival microbiota of 25 patients with untreated $\mathrm{CP}$ using the Checkerboard DNA-DNA hybridization technique and found some unusual types of E. faecalis. Slots, et al.24 (1991) identified a prevalence of $23 \%$ of enteric bacteria in patients with periodontitis.

In the present study, teeth from which samples of sub- and supragingival plaques were collected showed pulp vitality and absence of dental caries.

$P$. gingivalis was found in $23.5 \%$ of saliva and tongue dorsum samples, $30 \%$ of buccal mucosa samples, $40 \%$ of supragingival plaque samples, and $53.5 \%$ of subgingival plaque samples. There were no significant statistical differences between the sites analyzed $(p=0.068)$. These results are in agreement with previous findings. Wahlforst, et al. ${ }^{28}$ (1995) studied subgingival plaques of 36 patients with $\mathrm{CP}$ and found a prevalence of $P$. gingivalis of $56 \%$ using PCR and $42 \%$ using cultures. Mombelli, et al. ${ }^{18}$ (2001) found a prevalence rate of $59 \%$ in subgingival plaques after treatment and advanced periodontal disease. Yano-Higuchi, et al. ${ }^{31}$ (2000) found a prevalence of $64.3 \%$ of $P$. gingivalis in subgingival plaques of 21 subjects with adult periodontitis using cultures. Kumar, et al. ${ }^{11}$ (2003) examined subgingival plaques of 66 patients with $\mathrm{CP}$, and found a prevalence of $88 \%$ of $P$. gingivalis using PCR. Gajardo, et al. ${ }^{5}$ (2005) detected a prevalence of $76.4 \%$ of $P$. gingivalis in subgingival plaques of patients with CP using cultures. Cortelli, et al. ${ }^{3}$ (2005) found a prevalence of $76 \%$ of $P$. gingivalis in subgingival plaques of 203 subjects with CP using PCR. Ledder, et al. ${ }^{12}$ (2007) found a prevalence of $29 \%$ of $P$. gingivalis in subgingival plaques of 47 subjects with CP using PCR multiplex.

$P$. intermedia had a prevalence rate of $23.5 \%$ in saliva, $33.5 \%$ in tongue dorsum, $26.5 \%$ in buccal mucosa, $33.5 \%$ in supragingival plaque and $30 \%$ in subgingival plaque. There were no significant statistical differences between the sites analyzed $(p=0.895)$. According to López, et al. ${ }^{16}$ (2000), the prevalence of $P$. intermedia in subgingival plaques of 60 subjects with $\mathrm{CP}$ was $33 \%$ in a study using DNA probes. Mombelli, et al. ${ }^{18}$ (2001) found a prevalence of $40.6 \%$ in subgingival plaques after treatment of advanced periodontitis using cultures. Gajardo, et al. ${ }^{5}$ (2005) found a prevalence of $35.2 \%$ of $P$. intermedia in subgingival plaques of patients with $\mathrm{CP}$ using cultures.

Ximenez-Fyvie, et al. ${ }^{30}$ (2000) compared the microbial composition of supra- and subgingival plaques in 23 patients with adult periodontitis. Periodontal pathogens were detected in supragingival plaque from sites in which subgingival samples were negative for the same species. Supragingival plaque can harbor putative periodontal pathogens, which suggests that this environment may be a reservoir of such species and for the spread of infection or reinfection of subgingival sites.

Mager, et al. ${ }^{17}$ (2003) analyzed the proportions of bacterial species in samples from oral soft tissue surfaces and saliva in healthy adults and compared microbiotas with those of supra- and subgingival plaque. In average, all of the species tested were found in all of the sampled surfaces. The major differences were in the proportion of colonization of the different surfaces, which suggests that receptors, co-aggregation or local habitat differences may play major roles in defining community structure. The microbial composition of saliva was most similar to that found on the lateral and dorsal surfaces of the tongue, suggesting that these surfaces may be the major sources of salivary bacteria. The microbiotas colonizing the remaining surfaces showed great similarities to each other, but differences were detected between surface sites. Plaques on teeth were somewhat similar to each other, but quite different from the microbiotas on soft tissue surfaces and in saliva. However, as pointed out above, tooth-colonizing species were detected on soft tissues. Haffajee, et al. ${ }^{8}$ (2008) observed that in supragengival biofilm samples were similar to those found in subgingival plaque samples with a few minor differences.

The results of the present study are in agreement with values found in other investigations, particularly when some characteristics of variables and methods

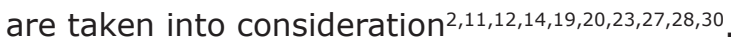

The method used in this study confirmed results obtained by other authors ${ }^{1,20}$, which indicated that the PCR method can be used in epidemiological studies to analyze the prevalence of selected bacteria in different populations. According to Oho, et al. $^{20}$ (2000), PCR is simpler than the traditional culture methods and provides results in a few hours. Colombo, et al. ${ }^{1}$ (1998) reported that the levels of "classic" periodontal pathogens such as $B$. forsythus, $P$. gingivalis and $A$. actinomycetemcomitans do not appear to be elevated in most refractory patients. According to their study, these organisms should be detected by more sensitive means, such as PCR, to examine their roles in periodontal diseases.

The risks and benefits of molecular techniques to achieve the main objective of this study indicate that multiplex PCR is adequate to determine the prevalence of bacteria in several intraoral sites.

\section{CONCLUSIONS}

All the bacterial species under study were identified in intraoral sites of our patients. The 
prevalence rates for $S$. mutans, $P$. gingivalis and $P$. intermedia were high in intraoral sites, but low for E. faecalis. Multiplex PCR proved to be an adequate method for epidemiological studies.

\section{ACKNOWLEDGMENTS}

This study was supported in part by grants from the Nacional Council for Scientific and Technological Development (CNPq grants 302875/2008-5 to C.E.). We thank Prof. Dra. Denise Madalena Palomari Spolidorio (Araraquara Dental School, São Paulo State University, UNESP, Brazil) for all suggestions to this study.

\section{REFERENCES}

1- Colombo AP, Haffajee AD, Dewhirst FE, Paster BJ, Smith CM, Cugini $\mathrm{MA}$, et al. Clinical and microbiological features of refractory periodontitis subjects. J Clin Periodontol. 1998;25:169-80.

2- Colombo AP, Teles RP, Torres MC, Souto R, Rosalém W Jr, Mendes MC, et al. Subgingival microbiota of Brazilian subjects with untreated chronic periodontitis. J Periodontol. 2002;73(4):360-9.

3- Cortelli SC, Feres M, Rodrigues AA, Aquino DR, Shibli JA, Cortelli JR. Detection of Actinobacillus actinomycetemcomitans in unstimulated saliva of patients with chronic periodontitis. J Periodontol. 2005;76(2):204-9.

4- Davey ME, Costerton JW. Molecular genetics analyses of biofilm formation in oral isolates. Periodontol 2000. 2006;42:13-26.

5- Gajardo M, Silva N, Gómez L, León R, Parra B, Contreras A, et al. Prevalence of periodontopathic bacteria in aggressive periodontitis patients in a Chilean population. J Periodontol. 2005;76(2):289-94.

6- Genco RJ, Sojar H, Lee JY, Sharma A, Bedi G, Cho MI, et al. Porphyromonas gingivalis fimbriae: structure function and insertional in inactivation mutants. In: Genco R, Hamada S, Lehner T, McGhee J, Mergenhagen S, eds. Molecular pathogenesis of periodontal disease. Boca Raton: American Society for Microbiology Press; 1994. p.13-23.

7- Haffajee AD, Socransky SS. Introduction to microbial aspects of periodontal biofilm, communities, development and treatment. Periodontol 2000. 2006;42:7-12

8- Haffajee AD, Socransky SS, Patel MR, Song X. Microbial complexes in supragingival plaque. Oral Microbiol Immun. 2008;23(3):196-205

9- Hafström C, Dahlén G. Pathogenicity of Prevotella intermedia and Prevotella nigrescens isolates in a wound chamber models in rabbits. Oral Microbiol Immun. 1997;12(3):148-54.

10- Holt SC, Kesavalu L, Walker S, Genco CA. Virulence factors of Porphyromonas gingivalis. Periodontol 2000. 1999;20:168-238.

11- Kumar PS, Griffen AL, Barton JA, Paster BJ, Moeschberger ML, Leys EJ. New bacterial species associated with chronic periodontitis. J Dent Res. 2003;82(5):338-44.

12- Ledder RG, Gilbert P, Huws SA, Aarons L, Ashley MP, Hull PS, et al. Molecular analysis of the subgingival microbiota in health and disease. Appl Environ Microbiol. 2007;73(2):516-23.

13- Lembo FL, Longo PL, Ota-Tsuzuki C, Rodrigues CR, Mayer MP. Genotypic and phenotypic analysis of Streptococcus mutans from different oral cavity sites of caries-free and caries-active children. Oral Microbiol Immunol. 2007;22(5):313-9.
14- Loesche WJ. Role of Streptococcus mutans in human dental decay. Microbiol Rev. 1986;50(4):353-80.

15- Loesche WJ, Syed SA, Laughon BE, Stoll J. The bacteriology of acute necrotizing ulcerative gingivitis. J Periodontol. 1982;53(4):223-30

16- López NJ. Occurrence of Actinobacillus actinomycetemcomitans, Porphyromonas gingivalis, and Prevotela intermedia in progressive adult periodontitis. J Periodontol. 2000;71(6):948-54.

17- Mager DL, Ximenez-Fyvie LA, Haffajee AD, Socransky SS. Distribution of selected bacterial species on intraoral surfaces. J Clin Periodontol. 2003;30(7):644-54

18- Mombelli A, Schmid B, Rutar A, Lang NP. Persistence patterns of Porphyromonas gingivalis, Prevotella intermedialnigrescens and Actinobacillus actinomycetemcomitans after mechanical therapy of periodontal disease. J Periodontol. 2001;71(1):14-21.

19- Murray BE. The life and times of the Enterococcus. Clin Microbiol Rev. 1990;3(1):46-65.

20- Oho T, Yamashita Y, Shimazaki Y, Kushiyama M, Koga T. Simple and rapid detection of Streptococcus mutans and Streptococcus sobrinus in human saliva by polymerase chain reaction. Oral Microbiol Immunol. 2000;15(4):258-62.

21- Paster BJ, Boches SK, Galvin JL, Ericson RE, Lau CN, Levanos $\mathrm{VA}$, et al. Bacterial diversity in human subgingival plaque. J Bacteriol. 2001;183(12):3770-83.

22- Sakai VT, Campos MR, Machado MA, Lauris JR, Greene AS, Santos CF. Prevalence of four putative periodontopathic bacteria in saliva of a group of Brazilian children with mixed dentition: 1-year longitudinal study. Int J Paediatr Dent. 2007;17(3):192-9.

23- Seoul JW, Cho BH, Chung CP, Bae KS. Multiplex polymerase chain reaction detection of black-pigmented bacteria in infections of endodontic origin. J Endod. 2006;32(2):110-4.

24- Slots J, Rams TE, Feik D, Taveras HD, Gillespie GM. Subgingival microflora of advanced periodontitis in the Dominican Republic. J Periodontol. 1991;62(9):543-7.

25-Socransky SS, Haffajee AD. Microbial mechanisms in the pathogenesis of destructive periodontal diseases: a critical assessment. J Periodontal Res. 1991;26(3 Pt 2):195-212.

26- Socransky SS, Haffajee AD, Cugini MA, Smith C, Kent RL Jr. Microbial complexes in subgingival plaque. J Clin Periodontol. 1998;25(2):134-44.

27- Sundqvist G, Figdor D. Life as an endodontic pathogen. Ecological differences between the untreated and the root-filled root canals. Endod Topics. 2003;6:3-28

28- Wahlfors J, Meurman JH, Väisänen P, Alakuijala P, Korhonen A, Torkko $\mathrm{H}$, et al. Simultaneous detection of Actinobacillus actinomycetemcomitans and Porphyromonas gingivalis by a rapid PCR method. J Dent Res. 1995;74(11):1796-801.

29- Wu H, Fan M, Zhou X, MO A, Bian Z, Zhang Q, et al. Detection of Streptococcus mutans and Streptococcus sobrinus on the permanent first molars of the Mosuo people in China. Caries Res. 2003;37(5):374-80. 30- Ximénez-Fyvie LA, Haffajee AD, Socransky SS. Microbial composition of supra and subgingival plaque in subjects with adult periodontitis. J Clin Periodontol. 2000;27(10):722-32.

31- Yano-Higuchi K, Tamakatsu N, He T, Umeda M, Ishikawa I. Prevalence of Bacteroides forsythus, Porphyromonas gingivalis and Actinobacillus actinomycetemcomitans in subgingival microflora of Japanese patients with adult and rapidly progressive periodontitis. J Clin Periodontol. 2000;27(8):597-602. 